\title{
Path Dependence And Behavorial Lock-In At Work: The Challenge Of Sustaining High Performance Work Systems In The U.S.
}

William Barnes, University of Portland, USA

\begin{abstract}
This article draws on path dependency literature and recent extensions to frame the evolution of high performance work systems (HPWS) in the U.S. and to reflect on the implications for firms and policy. The article briefly discusses institutional and social influences in the U.S. context that may be "locking in" managerial behavior that can prevent HPWS from diffusing or that renders HPWS vulnerable over time. In the face of this, in the short run firms may need to insulate the organization from institutional pressures and behavior that can erode new work systems. The article concludes by noting corporate governance models that elevate employee voice and security may be more compatible with HPWS for the long term.
\end{abstract}

Keywords: Behavioral Lock-in; Path Dependency; Path Creation; High Performance Work Systems

\section{INTRODUCTION}

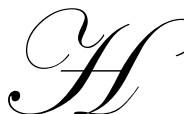

igh performance work systems - commonly defined as a set of complementary work practices that include substantive worker participation, effective employee training and learning, employee incentive pay, and relatively higher job security - have received growing attention in the past two decades for their promise in terms of a variety of firm level outcomes for both employees and employers. Yet despite growing empirical evidence of potential gains in employee outcomes and firm productivity and profitability, understanding what these "systems" are and how to implement and sustain them over time in the U.S. and other settings remains difficult.

Path dependency literature and recent extensions can help to frame developments in workplace evolution to better understand how to overcome barriers to meaningful work design in a particular country. After briefly discussing some recent extensions and applications to path development theory, this paper then frames the evolution of work in the U.S. using this literature. Drawing on casework by the author and other cases to discuss the potential difficulties in implementing and sustaining HPWS in a U.S. setting, the paper then briefly addresses implications for firms and for policy.

\section{PATH DEPENDENCY, PATH CREATION, AND “BEHAVIORAL LOCK-IN"}

Paul David (1985) and Brian Arthur's $(1989,1990,1994)$ early work utilised a path dependency framework to explain the "lock-in" of sub-optimal technology such as the QWERTY keyboard over the DVORAK keyboard and VHS over BETA. This challenge to standard neoclassical orthodoxy was later questioned, with critics claiming that QWERTY and VHS were actually efficient solutions, and that the path dependency thesis is suspect (Liebowitz and Margolis, 1990, 1995). David, Arthur and others responded by arguing that even if these particular examples are not clearly suboptimal or optimal, it does not negate the robustness of the path dependency framework (David, 2001). Arthur pointed out that his graduate training did not adequately teach him how history shapes the market process in these and other examples. In Arthur's words, "The issue was that these markets worked differently than I had been taught they did." (Gomes, 1998) 
Veblen, Myrdal and other institutionalists long ago preceded this line of argument, pointing out that historical events and habit are critical in shaping economic choices, whether or not this leads to an "efficient" outcome (Veblen, [1899], 1994). Through a historical, evolutionary process, the basic argument is that markets can lock-in sub-optimality (or optimality).

David's and Arther's path dependency work primarily develops the notion that a suboptimal technology can emerge and lock in over time because of historical luck, the ability to move through a learning curve first, and the presence of network effects. Other work has begun to extend the theoretical framework and its application further. In a paper drawing on path dependency and related "path creation" literature typified by Garud and Karnoe's work (2001), Stack and Gartland (2003) stress that lock-in (of either a sub-optimal or an optimal result) should be seen as a process infused with agency, not as the result of a random event or historical accident. Change agents mindfully react to and shape their environment by altering established routines, modifying existing institutions, and embracing the unfamiliar until a new structure results. They use the American Brewing industry as a case to show that brewing shippers intentionally set about during Prohibition to influence legislation in their favor, resulting in more expensive (and inferior) mass-produced beer for the masses when Prohibition was lifted.

In another paper, Barnes, Stack and Gartland (2004) extend the traditional analysis of technology lock-in and briefly apply it to three separate cases; brewing, medical records, and work systems. ${ }^{1}$ Coining the term "behavioral lock-in," Barnes, Stack and Gartland draw on David's 1985 article to highlight the relatively undeveloped behavioral component of David's assertion that "path dependencies arise in the presence of strong technical interrelatedness, scale economies, and irreversibilities due to learning and habituation." They stress that consumer, user, and employee habituation over time can lock-in a particular product or practice, and that this behavior can effectively constrain or undermine a superior product or practice. For example, documenting the superiority of electronic medical records (EMR) over paper records, they ask a key question: why have physicians been so slow to adopt them? Their answer is not financial - evidence suggests that switching would save doctors money - but rather that physicians are behaviorally "locked-in" because of habit and their desire to maintain control over patient data. In the face of this, the relatively more efficient solution is not automatic. They argue that electronic medical records may win out in the long run, but whether or not this occurs may depend critically on champions within the medical community and on broader change (e.g. legislative change) - which may help to forge a new path.

A variety of later work has cited behavioral lock-in and developed other examples. For example, Maréchal $(2009,2010)$ has written a series of papers investigating energy inefficiency and "carbon lock-in" due to behavioral patterns in the economy. According to Maréchal, traditional economic incentives do not work as anticipated because they typically neglect the role of habits; he argues that nuanced policy drawing on the insights of social identity theory and social comparison theory in psychology has a better chance of altering the behavior of energy consumers.

\section{HIGH PERFORMANCE WORK SYSTEMS}

One of the key points of the stories above is that end user or employee habituation can impede or undermine the diffusion of a potentially more efficient product, practice, or technology, perhaps particularly when a potential loss of power is concerned. Many of the cases involve lock-in of technology, but the concept of path dependency, path creation, and lock-in can be fruitfully applied to explore other outcomes in the economy. A story that parallels the cases detailed above revolves around recent trends in the evolution of work in the U.S.

In the last three decades, many organizations in the U.S. began to modify their traditional Taylorist/ Fordist work systems due to a steep increase in competition in increasingly global markets. For much of the last century under Taylorism and Fordism, low trust, tight supervision, relatively adversarial bargaining, and hundreds of rigid job classifications characterized the work environment. By the late 1970s and early 1980s, U.S. firms became more interested in work design and production techniques inspired by Charles Deming that were modified and time-tested successfully in Japan (Womack et al., 1990; Kenney and Florida, 1993). U.S. firms in many industries had no choice - they had to try something different or face decline and possible extinction. The successful NUMMI experiment

${ }^{1}$ The current paper further develops the work systems case. 
between GM and Toyota in the 1980s offered even more reason to believe in the competitive advantages of workplace design. Largely using the same UAW employees and with minimal modification of factory technology, Toyota helped to make one of GM's worst plants into its best, doubling productivity in a few years and producing higher quality cars than any other domestic auto plant (Levine, 1995).

Despite the success of NUMMI and other plants, many domestic organizations experimenting with work initially implemented "new" practices with little thought for how they fit together with other components (Appelbaum and Batt, 1994). These individual new practices included: new recruitment and selection techniques, increased employee participation in decisions (both on and off-line), work teams, kaizening (continuous, incremental improvement of production, work, and the product), increased on and off line training, labor management cooperation, trust building measures, increased job security measures, information sharing, measures to compress status differentials, incentive pay, and employee stock ownership plans. The initial introduction of quality circles (often without other practices) in the 1980s is a prime example of early failure, and the evidence that these practices individually contribute to increased performance outcomes is fairly thin (Lawler, 1987; Levine and Tyson, 1990; Combs et al., 2006).

Over time many researchers and practitioners began to argue that a complementary "system" of work practices and employee-relations reform offers the best chance for increased firm performance. Although there is a long history of attempting to define what these practices are and how they are complementary, the contours of a broad consensus began to emerge in the 1990's. Now often labeled "high performance work systems," the core complementary practices of these systems can be grouped under three categories: 1) substantive employee "participation" in production, 2) increased employee training, and 3) increased incentives for employees - including incentive pay and relative job security (Levine and Tyson, 1990; MacDuffie, 1995; Appelbaum et al, 2000). In a nutshell, empowered, well-trained employees agree to work in a much more flexible, team centered work environment with increased responsibility for making lower level managerial decisions and increased capacity and authority for improving the work and production process. In return for increased commitment to the work system and the production process, employees receive the intrinsic rewards from more autonomy and authority, and as well as extrinsic rewards such as greater pay and job security relative to older models of work. Taken together, this set of work practices equips employees with the information, skills, motivation and flexibility necessary to create competitive advantage.

Do these new "work systems" work? Noting that there is still debate about what exactly is critical in these systems, evidence is mounting that many firms do manage to increase performance measures in the U.S. and other countries given sufficient time. The evidence seems to be especially clear for measures of productivity in manufacturing (Ichniowski et al, 1997; Baker, 1999; Appelbaum et al, 2000; Combs et al, 2006). There is also evidence that (often initially expensive) high performance work systems increase financial performance (Huselid, 1995). Finally, there is also growing evidence of increased job satisfaction, increased intrinsic rewards, and increased earnings for employees (Berg, 1999; Appelbaum et al, 2000).

\section{BEHAVIORAL LOCK-IN AT WORK}

So given the allure of better outcomes, why don't all firms in the U.S. implement and sustain work systems that have these components? High performance work systems are seemingly diffusing more unevenly than economic theory would imply, and many show signs of vulnerability and tenuousness even after being successfully implemented. Analogous to the failure of quality circles in the 1980 s, there is evidence that the "full blown" versions of HPWS are rarer than one would expect and can at least partially revert back to older models of work (Appelbaum and Batt, 1994; Pfeffer, 1996, 1998; Osterman, 1994,1998; Tippet, 1997; Barnes, 2001;Vallas et al, 2003; Godard, 2004; Blasi et al., 2006, Kersley et al., 2006, Lynch, 2007). Using the concepts of path dependency and behavioral lock-in, this next section briefly explores possible reasons for this.

First, strategic managers in the U.S. answer to shareholders first, and this can be problematic for work systems that demand initially higher resources and increased commitment to employees. Despite recent increasing interest in stakeholder theory and corporate social responsibility on the part of academics and practitioners, the U.S. corporate governance environment arguably remains shareholder based and oriented towards measurable cost 
reduction and boosting profits for the next quarter (Laverty, 2006; Jackson et al., 2011). By biasing strategic managers towards short-term financial metrics, this may lock in behavior that undermines the practices necessary to create and then sustain a workplace environment stressing greater autonomy, security, and pay for performance for employees. Paradoxically, high performance work systems require increased commitment from employees even as pressures from largely absentee, uninvolved shareholders in the U.S. invite less commitment to employees. Constant pressure to boost share price can lead to a spiral of measurable short term cost cutting. Measurable cost cutting often means labor costs. For example, in downturns the first "locked-in" instinct of managers in the U.S. may still be to lay off employees, and yet relative job security is a critical component for participatory work systems that ask employees to find ways to boost productivity. If employees suspect that more involvement and participation will result in less job security because they can "suggest themselves out of a job," particularly in a fragile economy, they may rationally hold back on this behavior, undermining the intent of the work system.

Related to this, training and trust building associated with HPWS takes time, money, and persistence; done right this can bear rich rewards in the long run, but the markets may not reward managers for this kind of long run behavior. Adequately training employees to enable them to make substantive improvements in an organization's productivity is initially expensive and takes an ability to see beyond the next quarter. Investing time and energy to create a higher trust internal environment takes sustained commitment and an awareness that trust can evaporate quickly due to unpredictable behavior on the part of management. Managers need to understand that these up front expenses are actually investments in a long-term future and consistently make this case.

Second, even if new participatory work systems are carefully adopted to a particular firm and industry context and fully supported in terms of time and resources, publicly held firms in the U.S. can be easily bought and sold - often whether other stakeholders in the work and production system (e.g. employees, managers, suppliers, and minority long-term shareholders) approve or not. Takeovers can quickly result in reduced trust, security, and autonomy as new owners, often with a more traditional perspective on work systems, begin pressuring executives and managers to "cherry pick" the new work system to cut costs (Barnes, 2001). Thus, even if particular managers believe that high performance work systems are optimal in the long run and work to support them, financial markets may continuously send a different signal, ultimately replacing managers who do not focus on short-term financial metrics.

Third, managers in the U.S. are also steeped in a long tradition of top down hierarchical control, with jackpot pay rewards skewing to the highest levels (Singer, 2012). With control, pay and prestige concentrated in high level positions, managers attempting to implement and maintain truly empowering HPWS that elevate employee voice are doing so in an environment that can send mixed messages about how control and rewards are distributed within the firm. Although U.S. managers may say they want to share the power and the gains associated with initially successful work systems, it is arguably very difficult to do this in an environment that stresses and rewards the "pivotal" roles of solitary individuals and managers.

Fourth, managers commonly introduce changes in work organization in moments of crisis, when they are facing decline or possible bankruptcy. Employees understand this and may be skeptical of true buy-in on the part of senior managers. For long run success, managers need to wean themselves of authoritarian tendencies, and using authoritarian leadership under duress to implement and drive the design of work signals that the firm and top management is not credible (Pfeffer, 1996; Gilmore et al., 1997). High performance work systems are fundamentally bottom up, and managers need to learn how to cede some authority and approach decisions differently.

Finally, all of this occurs in an international context where domestic firms implementing higher wage, high performance work systems may often be competing with low wage firms abroad that readily pass off negative externalities because of relatively weaker environmental and labor laws. Without a level playing field, managers in the U.S. implementing work systems with higher standards may face consistent pressure to lower those standards.

\section{IMPLICATIONS \& CONCLUSIONS}

At the same time, the $21^{\text {st }}$ century represents an unprecedented challenge as organizations begin to face the simultaneous problems of climate change, degraded resource stocks, energy uncertainty, and high levels of 
inequality and poverty. Employers and employees are thus under increasing pressure to flexibly and efficiently produce quality products and services that also minimize negative environmental and social impacts. Flexible and complementary workplace arrangements that support continuous employee learning and meaningful participation in improving work and production outcomes are appealing in this context, and yet countervailing forces and habits can pull key decision makers in other directions.

Path dependency theory and its extensions are helpful in illuminating how institutional constraints and behavioral lock-in can hinder meaningful and long-lasting workplace change, and how to address it. The theory implies that workplace change over the past three decades is an evolutionary market process that may not result automatically in HPWS; this parallels growing knowledge of other path dependency/path creation stories. In many of these cases, and certainly with the case of work evolution in the U.S., implementing a new practice (or product, or production process) may involve initial champions who path create in a way that takes into account broader constraints and respects and cultivates the respective stakeholders involved in reform. This takes a detailed understanding of the old path and the constraints that tend to lock in behavior that may impede and erode new alternatives.

In the case of U.S. workplace evolution, many firms successfully implementing these new systems in the past three decades acted like they believed there are basic constraints effectively "locking out" HPWS in the U.S., and they took steps to insulate plants from these constraints. For example, in steel and auto, executives and unions alike often felt the need to create green-field sites away from original brownfield production facilities, and also created separate labor management agreements. Firm decision makers also sought to create stable and long-termist ownership; in steel and auto, this often happened with a Japanese or other foreign partner. Unionized workplaces well trained in the requirements of these work systems helped to maintain the level and type of employee voice these work systems require, particularly in moments of ownership transition and economic uncertainty (Barnes, 2001). Thus, in the U.S context, individual organizations may need actors able to see the big picture and to champion and defend the new work system, helping to "path create" in the face of constraints.

Cultivating champions who can create adequate "insulation" and path create may be a short to mediumterm solution for particular organizations. The deeper question is how the most robust versions of high performance work systems - those including higher relative job security and greater employee voice and autonomy - can be sustained in the U.S. setting in the long-run. This requires a closer examination of broader institutional constraints on work systems and the conditions creating behavorial lock-in that can undermine these systems.

As noted above, corporate governance may be an important component of these broader institutional constraints. In Japan, where much of the innovation in work design away from Taylorism and Fordism occurred, the country remains resistant to governance reform that would significantly elevate shareholders and pressure managers to dismantle a more stakeholder and employee-oriented approach to governance. At the same time in the U.S., intense interest in appropriate models of firm governance continues as senior managers, investors, and customers increasingly realize that strategic CSR and operationalizing "sustainability" may be crucial for long-run competitive advantage. Much more work is needed to understand the mediating variables and drivers that lead to better performance in financial, social, and environmental outcomes, and how governance can affect those drivers.

High performance work systems, with their premium on eliciting continuous creativity and intelligence from employees, are well positioned to play a critical role in improving organizational outcomes, including social and environmental ones. However, to sustain commitment from employees, employers implementing and attempting to sustain these work systems need to respect the needs of employees. HPWS are premised on the notion that increased commitment from employees will help drive performance, but this is in return for commitment from employers in the form of higher rewards, including greater relative security, autonomy, and pay. If governance structures ultimately lock in managerial behavior running against the grain of HPWS through a propensity for short run cost cutting, mixed messages about control, and prematurely or unpredictably threating job security, then the governance model itself may need to be critically examined. As the questions have evolved from whether to implement HPWS to how to adopt them to their particular context and sustain them for the long term, it behooves researchers and practitioners to more carefully investigate and respect the broader forces at play that influence these work systems. 


\section{AUTHOR INFORMATION}

William Barnes, $\mathrm{PhD}$, is Associate Professor of Economics and Environmental Science at the University of Portland in Portland, Oregon. His research interests include barriers and pathways to clean technology and sustainable production systems, performance outcomes associated with CSR, and comparative economic institutions. E-mail: barnesw@up.edu

\section{REFERENCES}

1. Appelbaum, E. and R. Batt (1994). The New American Workplace. Ithica, ILR Press.

2. Appelbaum, Eileen, T. Bailey, P. Berg, and A. Kalleberg (2000). Manufacturing Advantage: Why High Performance Work Systems Pay Off. Ithica, Cornell University Press.

3. Arthur, B. (1989). Competing Technologies, Increasing Returns, and Lock-In By Historical Events. Economic Journal, 99: 116-31.

4. $\quad$ Arthur, B. (1990). Positive Feedbacks in the Economy. Scientific American, 262: 92-99.

5. $\quad$ Arthur, B. (1994). Increasing Returns and Path Dependence in the Economy. University of Michigan Press.

6. Baker, T. (1999). Doing Well By Doing Good: The Bottom Line on Workplace Practices. Washington, DC: Economic Policy Institute, 1999.

7. Barnes, W. (2001). The Challenge of Implementing and Sustaining High Performance Work Systems in the U.S.: an Evolutionary Analysis of I/N Tek and Kote. Notre Dame Press, Ph.D. Dissertation.

8. Barnes, W., M. Gartland, M. Stack, (2004). Old Habits Die Hard: Path Dependency and Behavioral LockIn. Journal of Economic Issues, 38 (2): 371-377.

9. Berg, P. (1999). The Effects of High Performance Work Practices on Job Satisfaction in the United States Steel Industry. Relations Industrielles, 54 (1): 111-35.

10. Blair, Margaret M. (1995). Ownership and Control. Washington, DC: Brookings Institution. 1995.

11. Blasi, J., D. Kruse (2006). U.S. High-Performance Work Practices at the Century's End. Industrial Relations, 45: 547-578.

12. Combs, L., Hall \& Ketchen (2006). How Much Do High Performance Work Practices Matter? A Meta Analysis of their effects on Organizational Performance. Personnel Psychology, 59: 501-528

13. David, P. (1985). Clio and the Economics of QWERTY. American Economic Review, Papers and Proceedings, 75: 332-337.

14. David, P. (2001). Path Dependence, its Critics, and the Quest for 'Historical Economics,' in P. Garrouste and S. Ioannides eds, Evolution and Path Dependence in Economic Ideas: Past and Present. London Edward Elgar.

15. Garud, R. and Karnoe, P. (2001). Path Dependence and Creation. in R. Garud and P. Karnoe eds Path Dependence and Creation, London: Lawrence Erlbaum Associates.

16. Gilmore, T., G. Shea, and M. Useem (1997). Side Effects of Corporate Cultural Transformations. Journal of Applied Behavioral Science, 33 (2): 174-89.

17. Godard, J. (2004). A critical assessment of the high-performance paradigm. British Journal of Industrial Relations, 42: 349-378.

18. Gomes, L. (1998, Feb. 25). QWERTY Spells a Saga of Market Economics. Wall Street Journal, 1.

19. Huselid, M. (1995). The Impact of Human Resource Management Practices on Turnover, Productivity, and Corporate Financial Performance. Academy of Management Journal, 38(3): 635-72.

20. Ichniowski, C., K. Shaw, and G. Prennushi (1997). The Effects of Human Resource Management Practices on Productivity: A Study of Steel Finishing Lines, American Economic Review. 87(3): 291-313.

21. Jackson, G, A Petraki (2011). Understanding Short-termism: The Role of Corporate Governance. Glasshouse Forum, Stockholm.

22. Kenney, M., R. Florida (1993). Beyond Mass Production: The Japanese System and Its Transfer to the U.S. New York: Oxford University Press.

23. Kersley, B., C. Alpin, J. Forth, A. Bryson, H. Bewley, J. Dix, and S. Oxenbridge, S. (2006). Inside the Workplace: Findings from the 2004 Workplace Employment Relations Survey. Routledge, London.

24. Laverty, K. J. (1996). Economic - Short-Termism: The Debate, The Unresolved Issues, and The Implications for Management Practice and Research. The Academy of Management Review, 21(3): 825860 . 
25. Lawler, E. (1987). Quality Circles, After the Honeymoon. Organizational Dynamics, 15: 42-54.

26. Leibowitz, S., S. Margolis (1990). The Fable of the Keys, Journal of Law and Economics, 33: 1-25.

27. Leibowitz, S., S. Margolis (1995). Policy and Path Dependence From QWERTY to Windows 95, Regulation. 18: 33-41.

28. Levine, D. (1995). Reinventing the Workplace: How Business and Employees Can Both Win. Washington, DC: Brookings Institution Press.

29. Levine, D. and L Tyson (1990). Participation, Productivity, and the Firm's Environment, in Blinder A. ed. Paying for Productivity. Washington, DC: Brookings Institution.

30. Lynch, L. (2007). The Adoption and Diffusion of Organizational Innovation: Evidence for the U.S. Economy. National Bureau of Economic Research Working Paper 13156.

31. MacDuffie, J. P. (1995). Human Resources Bundles and Manufacturing Performance: Organizational Logic and Flexible Production Systems in the World Auto industry. Industrial and Labor Relations Review, 48: 197-221.

32. Marechal, K. (2009). An Evolutionary Perspective on the Economics of Energy Consumption: The Crucial Role of Habits. Journal of Economic Issues, 43(1): 69-88.

33. Marechal, K, N. Lazaric (2010). Overcoming inertia: insights from evolutionary economics into improved energy and climate policies. Climate Policy, 10 (1): 103-11.

34. Osterman, P. (1994). How Common Is Workplace Transformation and Who Adopts It?, Industrial \& Labor Relations Review, 47 (2): 173-88.

35. Osterman, P. (1998). Work Organization in an Era of Restructuring: Trends in Diffusion and Impacts on Employee Welfare. MIT: Cambridge: Sloan School of Management.

36. Pfeffer, J. (1996). When It Comes to Best Practices Why Do Smart Organizations Occasionally Do Dumb Things? Organizational Dynamics, 25 (1): 33-34.

37. Pfeffer, J. (1998). Seven Practices of Successful Organizations. California Management Review, 40: 96124.

38. Singer, N (2012, Apr 7). In Executive Pay, A Rich Game of Thrones. New York Times,

39. Stack, M. and G. Miles (2003). Path Dependency, Path Creation, and Alternative Theories of the Firm. The Journal of Economic Issues, 37(2): 487-494.

40. Tippett, D. (1997). The UAW-Saturn Partnership: Is the Vision Fading? Engineering Management Journal, 9 (2): $15-20$.

41. Vallas, S. (2003). Why Teamwork Fails: Obstacles to Workplace Change in Four Manufacturing Plants. American Sociological Review, 68: 223-250.

42. Veblen, T ([1899],1994). The Theory of the Leisure Class. Penguin Books Edition.

43. Womack, J., D. Jones, D. and D. Roos (1990). The Machine that Changed the World: The Triumph of Lean Production, New York: Rawson Macmillan 


\section{$\underline{\text { NOTES }}$}

